\title{
Quality of Life and Depressive Symptomatology in Mothers of Individuals with Autism
}

\author{
Josieli Piovesan - Universidade de Passo Fundo, Passo Fundo, Brasil \\ Silvana Alba Scortegagna - Universidade de Passo Fundo, Passo Fundo, Brasil \\ Ana Carolina Bertoletti De Marchi - Universidade de Passo Fundo, Passo Fundo, Brasil
}

\begin{abstract}
This study aimed to investigate the Quality of Life (QOL) and the presence of the depressive symptoms in mothers of individuals with Autism Spectrum Disorder (ASD). Participants included 40 women, between 28 and 72 years old, married, with medium-low income and education levels, and with children between 10 and 40 years old. The instruments used were a social demographic and health characterization questionnaire, the World Health Organization Quality of Life (WHOQOL-Bref) questionnaire, the Beck Depression Inventory and Beck Hopelessness Scale (BDI-II and BHS), and the Baptista Depression Scale Adult Version (EBADEP A). The quality of life and the presence of depressive symptoms in mothers did not show significant correlation with the child's age. However, there was high and negative correlation between the quality of life and high levels of depressive symptoms and moderate correlation between environment and income. It concludes the necessity of preventive and therapeutic interventions for these mothers.

Keywords: psychological assessment, depression, autism spectrum disorder, quality of life
\end{abstract}

Qualidade de Vida e Sintomatologia Depressiva em Mães de Indivíduos com Autismo

\begin{abstract}
Resumo
Este estudo objetivou investigar a Qualidade de Vida (QV) e a presença de sintomas depressivos em mães de indivíduos com Transtorno do Espectro Autista (TEA), e a possível relação com a idade do filho. Participaram 40 mulheres, com idades entre 28 e 72 anos, casadas, com níveis de escolaridade e de renda médio-baixos, com filhos entre 10 e 40 anos. Como instrumentos, utilizaram-se questionário sociodemográfico e de caracterização da saúde, Questionário de Qualidade de Vida (WHOQOL-Bref), Inventário de Depressão e de Desesperança Beck (BDI-II e BHS), Escala Baptista de Depressão Versão Adulto (EBADEP A). A QV e a presença de sintomas depressivos nas mães não apresentaram correlação significativa com a idade do filho. Houve correlação alta e negativa entre QV e níveis elevados de sintomas depressivos e correlação moderada e positiva entre o domínio meio ambiente e renda. Conclui-se a necessidade de intervenções preventivas e terapêuticas às mães.

Palavras-chave: avaliação psicológica, depressão, transtorno do espectro autista, qualidade de vida
\end{abstract}

Calidad de Vida y Sintomatología Depresiva en Madres de Individuos con Autismo

\begin{abstract}
Resumen
Este trabajo investigó la Calidad de Vida (CV) y la presencia de síntomas depresivos en madres de individuos con Trastorno del Espectro Autista, y la posible relación con la edad del hijo. Participaron 40 mujeres, con edades entre 28 y 72 años, casadas, con niveles de escolaridad y renta de mediana a baja, con hijos entre 10 y 40 años. Como instrumentos se utilizaron: cuestionario sociodemográfico y de caracterización de la salud, Cuestionario de Calidad de Vida (WHOQOL-Bref), Inventario de Depresión y de Desesperanza de Beck (BDI-II y BHS), y Escala Baptista de Depresión Versión Adulto (EBADEP A). La CV y la presencia de síntomas depresivos en las madres no mostraron correlación significativa con la edad del hijo. Hubo correlación alta y negativa entre CV y niveles elevados de síntomas depresivos y correlación moderada y positiva entre el medio ambiente y la renta. Se concluye con la necesidad de intervenciones preventivas y terapéuticas a las madres.
\end{abstract}

Palabras clave: evaluación psicológica, depresión, trastorno del espectro autista, calidad de vida

\section{Introduction}

There has been a significant increase in the diagnosis of individuals with Autism Spectrum Disorder (ASD) in recent years. The international literature indicates a prevalence of approximately one case diagnosed in every 110 people (Autism and Developmental Disabilities Monitoring Network, 2012).

In Brazil and other Latin American countries, there are only preliminary data. A study conducted in a municipality in Southwest Brazil with a sample of 1.470 children between 7 and 12 years by Paula, Fombonne, Gadia, Tuchman, and Rosanoff (2011), found a prevalence of 27.2 children with ASD for every 10 thousand inhabitants, about $0.3 \%$. These findings were considered below international estimates, as it is likely that in Brazil there are 1.5 million people with the disorder.

According to the Diagnostic and Statistical Manual of Mental Disorders of the American Psychiatric Association (DSM-5, 2014), ASD is understood from two domains: one related to persistent impairment in reciprocal social communication and social interaction; 
and the other, concerning the presence of restricted and repetitive patterns of behavior and interests. Despite such criteria, the characteristics of the disease are manifested by a wide variety of symptoms and degrees of severity, which confers a peculiar character to each individual (DSM 5, 2014; Paula, Fombonne, Gadia, Tuchman, \& Rosanoff, 2011). In most cases, the chronicity and severity of symptoms demand intensive care throughout life, role that is usually taken up by the figure of the mother (Howlin, Goode, Hutton, \& Rutter, 2004; Martin \& Leon, 2008).

Literature suggests that the child's challenging behavior, the dependence in daily life activities, and the continuous demands, together with the need for economic, social, and psychological restructuring, present a potential character for the presence of high levels of stress in mothers who are caretakers (Benson \& Karloff, 2009; Gray, 2002; Martin \& Leon, 2008; Montes \& Halterman, 2008; Schmidt, Dell'Aglio \& Bosa, 2007). Sanini, Brum and Bosa (2010) and Gatzoyia et al. (2013) confirm that the constant and permanent care provided by the mother can be characterized as a potent stressor, with the possible implication of depression. In addition, the severity of ASD in children was associated with high levels of depressive symptoms in mothers (Benson, 2006), as well as with high level of stress in parents and teachers (Lecavalier \& Wiltz, 2006).

The specific needs of individuals with ASD require investment of time, financial resources, and adjustment in work projects and in daily routine. According to Ghanizadeh, Alishahi, and Ashkani (2009), some of the difficulties in the treatment of these patients are related to the high cost, the delay in receiving the care, long waiting lists, and the lack of specialized services. In line with these findings, a Brazilian study with parents of individuals with ASD pointed as main difficulties the quality of support received by health professionals, the high cost of consultations, the long wait for the service, the lack of consensus on the medication and interventions, and the delay in diagnosis (Semensato, Schmidt, \& Bosa, 2010).

The chronic nature of the disorder, the high degree of dependence associated with an increased number of diagnoses and increased longevity, require a greater amount of time spent by mothers on child care (Riviére, 2004; Schmidt, 2004). This scenario raises the need for a greater understanding of the disorder and its impact on the physical, psychological, family, and social level, in the child's different stages of development, in order to contribute for the implementation of actions that qualify the assistance to caregivers, especially to mothers.

A study by Piovesan, Freo and Scortegagna (2012) investigated the perception of women over the ageing of their children with ASD. The main results indicated concern for the child's future, especially regarding the fear of not having close and trusted people to understand the needs and provide the necessary care when they die.

Understanding the influence of the age factor in the well-being of mothers of people with ASD was also object of study by some international papers. On the one hand, there are studies in Turkey (Firat, Diler, Avic, \& Seydaoglu, 2002), in the United States (Lounds, Seltzer, Greenberg, \& Shattuck, 2007) and Australia (Gray, 2002) indicating an improvement in well-being over time. On the other, there are studies where age did not present relevance, or the passage of time revealed negative impacts, such as in those conducted in the United States (Barker et al, 2011; Smith, Seltzer, Tager-Flusberg, Greenberg, \& Carter, 2008 ), the UK (Cadman et al., 2012), and Greece (Gatzoyia et al., 2013).

In order to better understand the factors that can influence the well-being of mothers, the mentioned studies will be described in detail. Firat et al. (2002) compared the presence of depression in mothers of individuals with ASD and with intellectual disability. Among the results, mothers of individuals with ASD showed higher levels of anxiety and depression, and the youngest presented higher depression scores. Lounds et al. (2007) investigated maternal well-being in the period of transition from adolescence to adult life of people with ASD. There was a greater adaptation of mothers over time. Gray (2002) followed parents of individuals with ASD and found that the current situation was better than it had been a decade earlier, due to the improved capacity of self-management by the children, and greater access to appropriate services and support network.

Smith et al. (2008) compared mothers of children and adolescents with the disorder. There were high levels of distress in both groups, and more than one third had clinical scores above the clinical risk for depression. When the feelings of anger were investigated in both groups, mothers of adolescents showed higher levels, which may be related to the wear caused by the intense routine of care over the years.

Barker et al. (2011) examined the relationship between depressive symptoms and anxiety in mothers of children, adolescents, and adults with ASD. 
Depressive symptoms did not change over the 10 years of the study, however, at baseline, older mothers reported fewer symptoms of depression. In addition, the survey pointed out that in the presence of the child's behavioral problems, depressive symptoms and anxiety rose, as well as in the occasions when the social support network was not satisfactory. When the son developed more independence and autonomy, maternal anxiety was lower.

Cadman et al. (2012) compared families with children with ASD and children with Attention Deficit and Hyperactivity Disorder (ADHD). The research indicated that both disorders were associated with a high level of stress in caregivers, significantly higher in parents of individuals with ASD, and children between the ages of 14 and 24 are those who tend to generate more emotional and physical overload.

Gatzoyia et al. (2013), in a recent study, assessed the presence of depressive symptoms and psychological distress in parents of individuals with ASD. Younger parents and with lower financial resources had higher levels of psychological distress and showed more severe depressive symptoms.

Analyzing the mentioned studies, we observed that the findings about the influence of the age factor in children with ASD on maternal well-being are not conclusive. Seltzer, Krauss Orsmond and Vestal (2001), and Barker et al. (2011) and Cadman et al. (2012) argue that much of this result derives from the fact that the surveys tend to focus on childhood.

Although there is still lack of research to elucidate the implications of the aging of ASD children in maternal well-being, some studies have documented the occurrence of negative results (Blacher \& McIntryre, 2006; Duarte, Bordin, Yazigi, \& Mooney, 2005; Cadman et al., 2012; Duarte, Khanna et al, 2011; Firat et al, 2002). According to these authors, this occurs predominantly in caregivers of children with ASD compared to parents of children with a typical development or other medical conditions.

To better elucidate this issue, Tekinarslan (2013) compared the presence of depression and the perception of QOL in mothers of children with Down syndrome, cerebral palsy, and ASD. The results showed a significant negative correlation between maternal depression and QOL, especially in the domain psychological health. But the social networking domain showed a significant negative correlation of moderate magnitude. In this study, it was also found that older mothers presented more depressive symptoms, as well as impairment in QOL.
In the Brazilian scenario, Fávero-Nunes and Santos (2010) investigated the prevalence of dysphoria and depression and the relationship with QOL in mothers of children with ASD. Among the participants, 15\% met the criteria dysphoria/depression, $70 \%$ considered their global QOL favorable, however, only $40 \%$ indicated satisfaction with their health. For the domains assessed by the WHOQOL-Bref, the physical was the best appreciated, while the environment was the worst. Furthermore, the findings reported significant association between the QOL and the presence of depressive symptoms.

Another study investigated the QOL of caregivers of children with ASD. The results indicated that the environment domain was the only one that showed a statistically significant correlation with the variables of education and social class. The data revealed that aspects such as access to leisure, health, and transport play an important role in the perception of QOL of participants (Barbosa \& Fernandes, 2009).

Trying to understand the impact of depressive symptoms on QOL, Lima (1999) points out that even the less severe symptoms are important, since their presence is commonly linked to the onset of more severe psychiatric disorders. The chronic and recurring character of depression majors the social, emotional, and economic impacts, significantly affecting the QOL and well-being of the individual and other family members (Lima \& Fleck, 2009). Sanini et al. (2010) and Fernandes (2009) reiterate that maternal depression also negatively affects the child, as it prevents care from being effectively performed.

Therefore, the increase in the number of individuals diagnosed with ASD, the need for a continuous caregiver, the psychosocial effects of raising a child with this disorder, and the few studies that contemplate the adolescence and adulthood of these individuals, indicate the need for further research. So, this investigation aimed to determine the association between QOL and depressive symptoms in mothers of individuals with ASD and the age of the child.

\section{Method}

\section{Participants}

Participants included 40 women, aged between 28 and 72 years old, married, with medium-low levels of education and income, with children aged between 10 and 40 years, with ASD, who attended specialized care institutions or special education schools, located 
in the regions Northwest of Rio Grande do Sul and West of Santa Catarina. The inclusion criteria included two aspects: i) having a child diagnosed with ASD for at least 1 year; ii) not having experienced stressful situations, such as unemployment, terminal illness, death of a loved one, serious accidents, divorce, marriage, or pregnancy - birth of a child, in the period of at least 6 months prior to the search.

\section{Instruments}

a) Socio-demographic and health questionnaire (regarding the mother and the child with ASD): with the aim to know about the health of mothers and their children. It consisted on a self-report instrument consisting of 47 simple choice questions and polyatomic measures, related to the occurrence of stressful situations experienced by the mother, 6 months prior to the survey. Information was obtained about their past and present life, history of depression, leisure activities, time of diagnosis of ASD, characterization of clinical symptoms, presence of comorbidities, expectations about the child's future. The questions were developed by the researchers considering the factors related to the research problem.

\section{b) Quality of Life Questionnaire (WHOQOL-} bref) (Fleck et al, 2000): intends to assess a general measure of quality of life. It is composed of 26 questions divided into four domains, physical, psychological, social, and environmental, and two questions on the global domain. The responses are rated on a 5-point Likert scale, which range from one to five. The closer the score to 100, the better is the perception of QOL. It has good internal consistency, discriminant validity, criterion validity, concurrent validity, and reliability test/retest (Fleck et al., 2000). In a later study (Moreno Faerstein, Werneck, Lopes, \& Chor, 2006), the internal consistency, measured by Cronbach's alpha, was 0.67 for the social relationships domain, 0.69 for the environment domain, 0.75 for the psychological domain, 0.79 for the physical domain, and 0.89 for the set of 26 items.

c) Beck Depression Inventory (BDI II) (Beck \& Steer, 1993a): adapted by Gorenstein, Pang, Argimon and Werlang (2011), it measures the presence and intensity of symptoms of depression. Composed of 21 items, each with four responses (except for items 16 and 18 , in which there are seven responses, without, however, varying the score), it implies increasing degrees of severity of depression with a score of $0-3$. In its composition, it presents items with cognitive-affective and somatic content such as pessimism, feelings of failure, social withdrawal, and sadness, among others. The total score ranks the intensity of depression in minimal, mild, moderate, and severe levels. In the reliability study, Cronbach's alpha for outpatients was 0.92, which is considered a high index.

d) Baptista Scale of Depression (adult version) (EBADEP-A) (Baptista, 2011): Brazilian instrument that aims to track depressive symptoms in psychiatric and non-psychiatric samples. It consists of 90 statements, presented in pairs, one positive and one negative, totaling 45 items. The answers are structured in a 4-point Likert scale, having zero as minimum score 135 as maximum; the higher the score, the greater the depressive symptoms. The EBADEP-A and the BDI measure the same construct, but the instruments differ in the number of descriptors, and in the amount in percentage of items for each major category of assessment, which is why the two instruments were used. In the precision study by Baptista, Cardoso, and Gomes (2012), Cronbach's alpha coefficient was 0.95 , considered excellent.

e) Beck Hopelessness Scale (BHS) (Beck \& Steer, 1993b): b): adapted to the Brazilian population by Cunha (2011), it aims to assess the extent of pessimism or the extent of negative attitudes about the future. It is a dichotomous scale, consisting of 20 statements. The sum of the items results in a total score, based on which it classifies hopelessness in minimal, mild, moderate, and severe. In terms of reliability, we found a satisfactory level of internal consistency $($ Cronbach's Coefficient $=0.86)$ (Paranhos, Argimon, \& Werlang, 2010).

\section{Proceeding}

Initially, we contacted specialized care institutions and special education schools in the regions Northwest of Rio Grande do Sul and West of Santa Catarina, which offered services to individuals with ASD. After obtaining the letter of authorization of these institutions, the project was submitted to the Research Ethics Committee of UFP, and was approved under the 185.924 Opinion on $01 / 16 / 2013$. Next, the participants were recruited, with the aid and information dispensed by professionals working at the partner institutions in the research. The meetings with the mothers were scheduled by phone, and occurred preferably on the premises of the institution. In case they could not commute, the contact happened in their own homes. After the objectives and procedures of the research were exposed, 
and the Informed Consent (IC) was signed, we proceeded to the administration of the Socio-demographic Questionnaire and characterization of the mother, the WHOQOL-bref, the BDI II, the EBADEP -A and BHS, respectively. The administration of the instruments was conducted individually and assisted manner, in a single session of about 2 hours.

\section{Data Analysis}

The data obtained through the research instruments were entered into a Microsoft Excel spreadsheet and statistical analysis was performed with SPSS 17.0 for Windows. Categorical variables were expressed as absolute and relative frequency and the number as mean \pm standard deviation or median (25th percentile - 75th percentile), as presented normal distribution or not, respectively. The correlations between numerical variables were evaluated using Spearman correlation. The associations between the presence of intellectual disability in the child and the scores of quality of life scales and depression were assessed using analysis of variance with one classification criterion. Significance was established at $p<0.05$.

\section{Results}

In the description of the results, first we will present the characterization of the participants and the previous clinical history; next, we will demonstrate the mean, standard-deviation, and the median of the instruments used in the research and, finally, the table of associations between the variables: child's age, maternal age, presence of feelings of hopelessness, depressive symptoms, as well as the total QOL and its domains.

The 40 study participants presented mean age of $45.5 \pm 12.5$ years, median time of study of 11 (5.5 13.0) years, 29 participants were married and 25 (62.5\%) did not engage in any remunerated activity. The mean per capita income was of $1.0(0.7-1.4)$ minimum wage, as described in table 1 . Among the 40 participants, 16 $(40 \%)$ said they had already been through a depressive episode, $14(35.0 \%)$ said that the (s) episode(s) started after the child's diagnostic investigation, while the other $2(5.0 \%)$ reported a previous episode. Eighteen (45.0\%) participants mentioned making use of medication: 5 $(27.8 \%)$ for depression, $5(27.8 \%)$ for hypertension, $4(22.2 \%)$ for anxiety, $2(11.1 \%)$ for insomnia, and 2 $(11.1 \%)$ for seizure.

The variables maternal age, years of education, marital status, area of residence, and work activity
Table 1

Mean, Standard Deviation, and Median of the SocioDemographic Characteristics of the Sample and Clinical Data

\begin{tabular}{ll}
\hline Variable & Mean Score \\
\hline Age (years) & $45.5 \pm 12.5$ \\
Child's age (years) & $19,0 \pm 7,9$ \\
Age of diagnosis (years) & $6.0(4.0-9.5)$ \\
Time of study (years) & $9.78 \pm 4.1$ \\
Income (per capita) & $1.0(0.7-1.4)$ \\
Marital status & \\
Single & $7(17.5 \%)$ \\
Married & $29(72.5 \%)$ \\
Widower & $4(10.0 \%)$ \\
Housing & $28(70 \%)$ \\
Urban & $12(30 \%)$ \\
Rural & $15(37.5 \%)$ \\
Work activity & \\
Previous depression & $16(40.0 \%)$ \\
\hline
\end{tabular}

Note. Values express mean \pm standard deviation, median (p25-p75) or absolute and relative frequency.

showed no statistically significant correlation with QOL and the presence of depressive symptoms. We evaluated the association between income and quality of life using the Spearman correlation coefficient and there was a statistically significant positive correlation, of moderate magnitude with the environment domain $\left(r_{\text {ho }}=0.42 ; p=0.007\right)$, i.e., the lower the income, the lower the fruition of the domain. It should be noted that, the environment domain refers to the physical safety and protection, home environment, financial resources, health, and social care - availability and quality, opportunities to acquire new information and skills, participation in, and opportunities or recreation/ leisure, physical environment (pollution/noise/traffic/ climate) and transport - (Fleck et al., 2000).

The average age of the child with ASD was $19.0 \pm 7.9$ years, the youngest with 10 and the oldest with 40 . With regard to the presence of comorbidities in children, all mothers mentioned an intellectual deficiency, with moderate to severe impairment. Other comorbidities were reported, such as epilepsy in 9 $(22.5 \%)$, cerebral palsy in $4(10.0 \%)$, Down syndrome in $2(5.0 \%)$, visual deficiency in $2(5.0 \%)$, ADHD in $2(5.0 \%)$, humor bipolar disorder in $2(5.0 \%)$, physical disabilities in 2, fetal alcoholic syndrome, Goldenhar 
syndrome, and microcephaly and macrocephaly, each in 1 in $1(2.5 \%)$.

The association between the presence of comorbidities in the child and maternal well-being was assessed by analysis of variance with a classification criterion. There was no difference between mothers of children with ASD with and without intellectual disabilities regarding the BDI $(13.2 \pm 7.6$ vs $9.8 \pm 8.7$, $F=\underline{0,1,726}, g l=1.38, p=0.197)$, EBADEP-A (41.2 \pm 20.2 vs $30.1 \pm 25.4, F=2.250, g l=1.38, p=0.142)$ and WHOQOL-Bref, (62.7 \pm 10.3 vs $65.6 \pm 12.0, F=$ $0.645, g l=1.38, p=0.427$ ), respectively. In sequence, we present the mean, standard-deviation, and median.

From the analysis of the instruments, it appears that the mean score of the WHOQOL-Bref was 64.3 \pm 11.1. Considering that the closer the score was to 100 , the better the perception of QOL, there is good appreciation of this construct, as $31(77.5 \%)$ mothers estimated QOL as "good".

With regard to health satisfaction, 20 (50\%) reported being "satisfied", 15 (37.5\%) "neither satisfied nor dissatisfied". We observed that QOL indicators were higher than those of health satisfaction, and the psychological domain was most popular, followed by physical, while the environment domain was the least scored. One aspect observed in this area was the question number 14 - "To what extent do you have opportunities for leisure activities?" - 20 (50\%) mothers indicated "very little", 13 (32.5\%) "moderate amount".

The BHS scale presented a median of 2.5 (1.0 to 5.0). Among the participants, 27 (67.5\%) had minimal symptoms, and 10, (25\%) moderate, showing hope towards the future. Throughout the administration of the scale, the mothers reported having difficulty to answer the questions. Between the lines, are: "I try not to think about the future," "we have to believe it will be better", "If I'm not well, who will take care of him?"

There were differences in the scores of instruments to assess depressive symptoms. The mean and standard deviation of the BDI-II was $11.3 \pm 8.3$, the EBADEP-A, $35.1 \pm-23.6$, with 40 of the 40 participants $(47.5 \%)$ presenting minimal symptoms, 12 (30 $\%)$ light, in the BDI, and $33(82.5 \%)$ mothers exhibited minimum symptoms in EBADEP-A. The high standard deviation found in the BDI and EBADEP indicates the heterogeneity of the sample, in which some mothers had higher levels of depressive symptoms, while others did not. These data also demonstrate particularities of the instruments which relate to the number of descriptors and items for each category of assessment, and
Table 2

Mean, Standard-Deviation and Median of Instruments Used in the Research

\begin{tabular}{ll}
\hline Variable & Mean score \\
\hline WHOQOL-Bref & $64.3 \pm 11.2$ \\
Physical & $67.3 \pm 17.7$ \\
Psychological & $67.8 \pm 12.3$ \\
Social relations & $63.3 \pm 18.4$ \\
Environment & $58.8 \pm 12.3$ \\
BHS & $2.5(1.0-5.0)$ \\
BDI & $11.3 \pm 8.3$ \\
EBADEP & $35.1 \pm 23.6$ \\
\hline
\end{tabular}

Note. Values express mean \pm standard deviation or median (p25 $-\mathrm{p} 75)$.

that may be useful for a refined research of depression symptoms in each of the mothers. Next, the correlation between the variables child's age, mother's age, presence of feelings of hopelessness, depressive symptoms, as well as QOL and its domains.

According to Table 3, there were no statistically significant correlations between the BHS, the BDI, the EBADEP, and the WHOQOL-bref and its domains, and maternal age. However, there was a statistically significant negative correlation, of strong magnitude, between high levels of depressive symptoms and QOL. The age factor, in this group, was not an important aspect in the perception of quality of life and depressive symptoms, but it was found that the greater the presence of depressive symptoms in mothers, the lower the perception of QOL and its domains.

\section{Discussion}

Socio-demographic and health (regarding the mother and the child with ASD) data allowed to confirm that most mothers are married, present a low socioeconomic status, do not work, dedicating themselves to their child's care. In their experiences they reported depressive episodes, after the onset of the diagnostic investigation of the disorder. These data confirm that mothers of children with ASD have given up their careers in order to ensure the medical and educational services necessary (Montes \& Halterman, 2008), and that having a child with the disorder constitutes a potentially stressful event, despite also depending on issues related to the child's emotional, biological, and personal characteristics (Sanini, Brum, \& Bosa 2010). 
Table 3

Correlation between the Age of the Child with ASD and the Research Instruments

\begin{tabular}{|c|c|c|c|c|c|c|c|c|c|}
\hline & $\begin{array}{c}\text { Child's } \\
\text { age }\end{array}$ & BHS & BDI & EBADEP & WHOQOL & Physical & Psychological & Social & Environment \\
\hline Child's age & - & tho $=-0.23$ & rho $=-0.21$ & rho $=-0.17$ & tho $=0.20$ & rho $=0.08$ & $\mathrm{tho}_{\mathrm{tho}}=0.18$ & tho $=0.13$ & $\mathrm{rho}=0.31 *$ \\
\hline BHS & - & - & $=0.68^{* *}$ & $=0.64 * *$ & $=-0.1^{* *}$ & $=-0.26$ & $\mathrm{rho}=-0.62^{* *}$ & $=-0.41 * *$ & $=-0.41 * *$ \\
\hline BDI & - & - & - & ${ }_{\mathrm{rho}}=0.93 * *$ & tho $=-0.73 * *$ & $\mathrm{rho}=-0.58 * *$ & $\mathrm{rho}=-0.69 * *$ & tho $=-0.48 * *$ & tho $=-0.48 * *$ \\
\hline EBADEP & & - & - & - & $=-0.73 * *$ & $=-0.61 * *$ & $=-0.68^{* *}$ & $=0.50^{* *}$ & $=-0.42^{* *}$ \\
\hline
\end{tabular}

$* p \leq 0.05 ; * * \leq 0.01$.

Participants in this study mentioned other difficulties: the delay in confirming the diagnosis of ASD, the comings and goings to health professionals and to adjust the use of medication. These results support the ideas of Ghanizadeh et al. (2009) and Semensato et al. (2010) that dissatisfaction with health services is one of the main problems perceived by parents of individuals with ASD, including aspects such as the high cost of consultations, the waiting lists, the lack of consensus on the diagnosis among the professionals, and the delay diagnosis.

Regarding the presence of depressive symptoms in mothers, there was no statistically significant difference regarding the age of the child with ASD. This aspect may be related to certain characteristics of the sample, as the presence of intellectual disability in all individuals with ASD and other comorbidities presented by some of them, which imply greater need for constant and permanent care.

This important characteristic of the sample, i.e., being caregivers of children who attend special schools, with low functioning levels, appears to have contributed to this outcome. These findings support Smith et al. (2008), Barker et al. (2011), who while searching for the levels of psychological distress in mothers of individuals with ASD, in different stages of development, did not find any changes. However, they differ from studies by Gray (2002), Lounds et al. (2007) in which there was a better adaption of mothers over time; and from Cadman et al. (2012) who observed overburden in caregivers who looked after people with ASD and ADHD in older ages. Among the reasons for these discrepancies, we verified that in the study by Gray (2002), mothers had greater access to appropriate nursing support services, which resulted in improved self-management of the children; in Lounds et al. (2007), children became more independent; and in Cadman et al. (2012) the study presented a sample with comorbidities.

It is noteworthy that in this study, there were differences in the rates of depressive symptoms indicators, being higher on the BDI and EBADE-A, and less expressive in quality of life in mothers with children with other comorbidities. These findings support the previous findings of increased risk for maternal depression in children with more severe ASD (Barker et al, 2011; Benson 2006; Benson \& Karloff, 2009). Allied to this, Lecavalier and Wiltz (2006) include an aggravating factor for individuals with comorbid conditions.

Due to the significant relationship with depression and the risk of suicide, hopelessness was also assessed. Most participants had mild symptoms of hopelessness. Considering that this variable investigates future prospects, which, in turn, leads to thoughts about the own aging and the child's, difficulties in addressing the issue can be inferred in the speech of mothers during the administration of the scale: "I try not to think about the future", "we have to believe it will be better", "If I'm not well, who will take care of him?" This corroborates Schmidt (2004) when he states that the feelings of mothers about the future of the child with ASD translate into insecurity and anxiety, as the studies by Piovesan, Freo and Scortegagna (2012), which found maternal concern for not being able count on close people to understand the needs and provide the necessary care to the child when they no longer live.

Regarding the variable of QOL and its domains (physical, psychological, social relationships, and environment), there were no significant correlations with the child's age, but the environment domain presented significant positive correlations of moderate magnitude with the income variable. This shows that participants with lower income showed less satisfaction with the environment, which confirms studies (Barbosa \& Fernandes 2009; Favero-Nunes \& Santos, 2010) that showed a significant correlation between the environment domain and social class, indicating that aspects such as access to leisure, health, and transportation services, play an important role in the perception of quality of life of mothers. 
Another factor that may be related to the low satisfaction with the environment domain refers to leisure activities and recreational opportunities. For many mothers, carrying out such activities is difficult due to lack of time, given the need for permanent and continuous care of their child with ASD. The low satisfaction with the domain and the correlation with the income variable indicate the need for public policies and strategies that provide these mothers with access to health services and education, leisure and recreation activities, and nursing support services. It is noteworthy that these aspects are relevant dimensions in the environment domain and consequently, in overall quality of life. It is noteworthy that in a recent study (Gatzoyia et al., 2013), younger parents and with disadvantaged financial resources, had higher levels of psychological distress and presented more severe depressive symptoms.

The survey data also indicated that mothers are less satisfied with their health than with their QOL in general. These results are similar to those of FáveroNunes and Santos (2010), which also found, in mothers, lower satisfaction in health than in quality of life in general. Thus, this suggests that the routine care provided to children often leads mothers to neglect their own care, impairing their wellbeing. Riviére (2004) highlights that the need for constant care, the investment of time, financial resources, and the adjustment of projects and routine often lead mothers to restrict their social life, to manage their lives around the son with ASD, and to forget their well-being.

The implications in the care of a child with ASD, the statistically significant correlation, of strong magnitude between QOL and depressive symptoms found in this group of mothers, highlights the importance of a careful look at maternal depression. Other studies (Fávero-Nunes \& Santos, 2010; Lima \& Fleck, 2009; Tekinarslan, 2013) confirm the high association between QOL and depressive symptoms.

Thus, we point out the importance of early identification of depressive symptoms in mothers of individuals with ASD, despite the occurrence of an established clinical scenario, given that they are commonly exposed to potentially stressful situations. The presence of some symptoms, without necessarily all the criteria that define the clinical scenario of depression, tends to interfere with QOL. In addition to this, thinking maternal wellbeing also implies benefits to the child with ASD, since their development, because of the importance of the mother-child relationship, tends to suffer negative interference in the presence of depressive symptoms in the mother (Fernandes, 2009).

\section{Conclusions}

This study investigated the association between QOL and depressive symptoms in mothers of individuals with ASD, and the child's age. Among the main findings are: (i) the lack of association between the quality of life and depressive symptoms and the child's age; (ii) higher depressive symptoms and lower quality of life in mothers of children with more severe ASD and with comorbidities; (iii) the greater the presence of depressive symptoms, the lower the perception of QOL; (iv) the lower the income, the lower the satisfaction on the environmental domain, i.e., lower conditions of access to health care, information, housing, leisure opportunities, recreation, social interaction and transportation, among others.

These results demonstrate the demand for preventive and therapeutic interventions. In this scenario, health professionals have an important role in the construction of meaning that each parent will make about having a child with ASD, in the appropriation of knowledge on the disorder, and in emotional support. In addition, the study recommends public investment in the improvement of environmental conditions, access to health, education, and leisure, to meet some of the difficulties pointed out by mothers in everyday life with the child.

Despite the relevance of these findings, this study had a limited number of participants and was conducted specifically with individuals with low cognitive function, with a restricted profile of the disorder, which does not allow generalizations. Indeed, studies with larger and diverse samples can help to further elucidate the association between the constructs quality of life and depressive symptoms, and the age of mothers of individuals with ASD.

Finally, the increased longevity of parents and the people with the disorder requires the development of new studies. Especially those aimed at evaluating the personal characteristics of caregivers, their resilience, their beliefs, and how public policies have advanced to meet this problem, increasing the understanding of the topic.

\section{References}

ADDM. Autism and developmental disabilities monitoring network. (2012). Retrieved from www.cdc. 
gov/ncbddd/autism/documents/addm-2012-community-report.pdf.

Baptista, M. N. (2011). Escala Baptista de depressão (Versão Adulto) - EBDEP-A. São Paulo: Vetor.

Baptista, M. N., Cardoso, H. F., \& Gomes, J. (2012). Escala Baptista de depressão (Versão Adulto) EBADEP-A: Validade convergente e estabilidade temporal. Psico-USF, 17(3), 407-416. Retrieved from http://www.scielo.br/pdf/pusf/v17n3/07. pdf

Barbosa, M. R. P., \& Fernandes, F. D. M. (2009). Qualidade de vida dos cuidadores de crianças com transtorno do espectro autístico. Revista Sociedade Brasileira de Fonoandiologia, 14(3), 482-486. doi: 10.1590/S1516-80342009000400009

Barker, E. T., Hartley, S. L., Seltzer, M. M., Floyd, F. J., Greenberg, J. S., \& Orsmond, G. I. (2011). Trajectories of emotional well-being in mothers of adolescents and adults with autism. Developmental Psychology, 47(2), 551-561. doi: 10.1037/a0021268

Beck, A. T., \& Steer, R. A. (1993a). Beck depression inventory. Manual. San Antonio, TX: Psychological Corporation.

Beck, A. T., \& Steer, R. A. (1993b). Beck hopelessness scale. Manual. San Antonio, TX: Psychological Corporation.

Benson, P. R. (2006). The impact of child symptom severity on depressed mood among parents of children with ASD: The mediating role of stress proliferation. Journal of Autism and Developmental Disorders, 36(5), 685-695. doi: 10.1007/ s10803-006-0112-3

Benson, P. R., \& Karlof, K. L. (2009). Anger, stress proliferation, and depressed mood among parents of children with ASD: A longitudinal replication. Journal of Autism and Developmental Disorders, 39(2), 350-362. doi: 10.1007/s10803-008-0632-0

Blacher, J., \& Mcintyre, L. L. (2006). Syndrome specificity and behavioural disorders in young adults with intellectual disability: Cultural differences in family impact. Journal of Intellectual Disability Reseach, 50(3), 184-198. doi: 10.1111/j.1365-2788.2005.00768

Cadman, T., Eklund, H., Howley, D., Hayward, H., Clarke, H., Findon, J., \& Glaser, K. (2012). Caregiver burden as people with autism spectrum disorder (ASD) and attention-deficit/hyperactivity disorder (ADHD): Transition into adolescence and adulthood in the United Kingdom. Journal of the American Academy of Child \& Adolescent Psychiatry, 51(9), 897-888. doi: 10.1016/j.jaac.2012.06.017

Cunha, J. A. (2011). Manual da versão em português das Escalas Beck. São Paulo: Casa do Psicólogo.

Duarte, C. S., Bordin, I. A., Yazigi, L., \& Mooney, J. (2005). Factors associated with stress in mothers of children with autism. Autism, 9(4), 416-427. doi: $10.1177 / 1362361305056081$

DSM 5. Manual diagnóstico e estatístico de transtornos mentais. 5 ed. Porto Alegre: Artemd, 2014.

Fávero-Nunes, M. A., \& Santos, M. A. (2010). Depressão e qualidade de vida em mães de crianças com transtornos invasivos do desenvolvimento. Revista Latino-Americana de Enfermagem, 18(1), 33-40. Retrieved from http://www.scielo.br/pdf/rlae/ v18n1/06.pdf

Fernandes, F. D. M. (2009). Famílias com crianças autistas na literatura internacional. Revista Sociedade Brasileira de Fonoandiologia, 14(3), 427-432. Retrieved from file:///D:/Users/Usu\%C3\%A1 rio/Downlo ads/542f4b400cf27e39fa99513c.pdf

Firat, S., Diler, R. S., Avic, A., \& Seydaoglu, G. (2002). Comparison of psychopathology in the mothers of autistic and mentally retarded children. Journal of Korean Medical Science, 17(5), 679-685. Retrieved from http://www.ncbi.nlm.nih.gov/ pubmed/12378023

Fleck, M. P., Lousada, S., Xavier, M., Chachamovich, E., Vieira, G., Santos, L., \& Pinzon,V. (2000). Aplicação da versão em português do instrumento abreviado de avaliação da qualidade de vida "WHOQOL-Bref". Revista de Saúde Pública, 34(2), 178-183. doi: 10.1590/S0034-89102000000200012

Gatzoyia, D., Kotsis, K., Koullourou, I., Goulia, P., Carvalho, A. F., Soulis, S., \& Hyphantis, T. (2013). The association of illness perceptions with depressive symptoms and general psychological distress in parents of an offspring with autism spectrum disorder. Journal Disability and Health, 7(2), 171-174. doi: 10.1016/j.dhjo.2013.10.008.

Ghanizadeh, A., Alishahi, M-J., \& Ashkani, H. (2009). Helping families for caring children with autistic spectrum disorders. Archives of Iranian Medicine, 12(5), 478-482. Retrieved from http://www.ams. ac.ir/AIM/09125/009.pdf 
Gorenstein, C., Pang, W. Y., Argimon, I. I. L., \& Werlang, B. S. G. (2011). Manual do Inventário de Depressão de Beck - BDI-II. São Paulo: Casa do Psicólogo.

Gray, D. E. (2002). Ten years on: A longitudinal study of families of children with autism. Journal of Intellectual e Developmental Disability, 27(3), 215-222. Retrieved from https://faculty.unlv.edu/sloe/ Courses/EPY\%20702/Class\%20Exercises/ Qualitative\%20Critique\%20Article/Qualitative_ Group4.pdf

Howlin, P., Goode, S., Hutton, J., \& Rutter, M. (2004). Adult outcome for children with autism. Journal of Child Psychology and Psychiatry, 45(2), 212-229. doi: 10.1111/j.1469-7610.2004.00215.x

Khanna, R., Madhavan, S. S., Smith, M. J., Patrick, J. H, Tworek, C., \& Becker-Cottril, B. (2011). Assessment of health-related quality of life among primary caregivers of children with autism spectrum disorders. Journal of Autism and Developmental Disorders, 41(9), 1214-1227. doi: 10.1007/ s10803-010-1140-6.

Lecavalier, L. L.S., \& Wiltz, J. (2006). The impact of behavior problems on caregiver stress in young people with Autism Spectrum Disorders. Journal of Intellectual Disability Research, 50(3), 172-183. doi: 10.1111/j.1365-2788.2005.00732.x

Lima, M. S. (1999). Epidemiologia e impacto social. Revista Brasileira de Psiquiatria, 21 (1 supl.), 1-5. doi: 10.1590/S1516-44461999000500002

Lima, A. F. B. S., \& Fleck, M. P. A. (2009). Qualidade de vida e depressão: Uma revisão da literatura. Revista de Psiquiatria do Rio Grande do Sul, 31(3 supl.), 0-0. Retrieved from http://www.scielo.br/pdf/rprs/ v31n3s0/v31n3a02s1.pdf

Lounds, J., Seltzer, M. M., Greenberg, J. S., \& Shattuck, P. T. (2007). Transition and change in adolescents and young adults with autism: Longitudinal effects on maternal well-being. American Journal on Mental Retardation, 112(6), 401-417. Retrieved from http:/ /www.waisman.wisc.edu/family/pubs/Autism $/ 2007 \% 20$ lounds $\% 20$ transition $\% 20$ and $\% 20$ change $\% 20$ maternal_well-being.pdf

Martín, M. A. M., \& León, M. C. B. (2008). Acercamiento a larealidad de las familias de personas con autismo. Intervención Psicosocial, 17(2), 215-230. Retrieved from http://scielo.isciii.es/scielo.php?pid=S1132$-05592008000200009 \&$ script $=$ sci_arttext
Montes, G., \& Halterman, J. S. (2008). Child care problems and employment among families with pre-school aged children with autism in the United States. Pediatrics, 122(1), e202-e208 doi: 10.1542/ peds.2007-3037

Moreno, A. B., Faerstein, E., Werneck, G. L., Lopes, C. S., \& Chor, D. (2006). Propriedades psicométricas do instrumento abreviado de avaliação de qualidade de vida da organização mundial da saúde no estudo pró-saúde. Caderno de Saúde Pública, 22(12), 25852597. doi: 10.1590/S0102-311X2006001200009

Paranhos, M. E., Argimon, I. I. L., \& Werlang, B. S. G. (2010). Propriedades psicométricas do inventário de depressão de Beck-II (BDI-II) em adolescentes. Avaliação Psicológica, 9(3), 383-392. Retrieved from http://pepsic.bvsalud.org/scielo.php?script $=$ sci_arttext\&pid =S1677-04712010000300005

Paula, C. S., Fombonne, E., Gadia, C., Tuchman, R., \& Rosanoff, M. (2011). Autism in Brazil: Perspectives from science and society. Revista Associação Medica Brasileira, 57(1), 2-5. doi: 10.1590/ S0104-42302011000100002

Piovesan, J., Freo, G. F., \& Scortegagna, S. A. (2012). O envelhecimento de sujeitos com transtorno do espectro autista sob a ótica de suas mães: Um relato de experiência. In Congresso Internacional de Estudos do Envelhecimento Humano - Os Desafios de Saber Envelhecer. Anais do Congresso Internacional de Estudos do Envelhecimento Humano, Passo Fundo, Brasil, 1(1), 186-187.

Riviére, A. (2004). O autismo e os transtornos globais do desenvolvimento. In C. Coll, A. Marchesi, J. Palácios et al. (Eds.), Desenvolvimento psicológico e educação: Transtornos de desenvolvimento e necessidades educativas especiais (pp. 234-253, $2^{\mathrm{a}}$ ed.). Porto Alegre: Artmed.

Sanini, C., Brum, E. H. M., \& Bosa, C. A. (2010). Depressão materna e implicações sobre o desenvolvimento infantil do autismo. Revista Brasileira Crescimento e Desenvolvimento Humano, 20(3), 809-815. Retrieved from http://pepsic.bvsalud.org/scielo.php?script=sci_arttext\&pid =S0104-12822010000300016

Schmidt, C. (2004). Estresse, autoeficácia e o contexto de adaptação familiar de mães de portadores de transtornos globais do desenvolvimento (Dissertação de Mestrado). 
Programa de Pós-Graduação em Psicologia - Universidade Federal do Rio Grande do Sul, Porto Alegre, Brasil.

Schmidt, C., Dell'Aglio, D. D., \& Bosa, C. A. (2007). Estratégias de coping de mães de portadores de autismo: Lidando com dificuldades e com a emoção. Psicologia Reflexão e Crítica, 20(1), 125-131. doi: 10.1590/S0102-79722007000100016

Seltzer, M. M., Krauss, M. W., Orsmond, G. I., \& Vestal, C. (2001). Families of adolescents and adults with autism: Uncharted territory. International Review of Research in Mental Retardation, 23, 267-294. doi: 10.1016/S0074-7750(00)80014-2

Semensato, M. R., Schmidt, C., \& Bosa, C. A. (2010). Grupo de familiares de pessoas com autismo: Relatos de experiências parentais. Aletheia, 32, 183-194. Retrieved from http://www.redalyc.org/articulo. oa?id $=115020838015$
Smith, L. E., Seltzer, M. M., Tager-Flusberg, H., Greenberg, J. S., \& Carter, A. S. (2008). A comparative analysis of well-being and coping among mothers of toddlers and mothers of adolescents with ASD. Journal of Autism and Developmental Disorders, 38(5), 876-889. doi: 10.1007/s10803-007-0461-6

Tekinarslan, I. C. (2013). A comparison study of depression and quality of life in Turkish mothers of children with Down syndrome, cerebral palsy, and autism spectrum disorder. Psychological Reports, 112(1), 266-287. doi: 10.2466/21.02.15. PR0.112.1.266-28

Recebido: 08/06/2014 Primeira reformulação: 29/01/2015 Segunda reformulação: 24/02/2015

Aprovado: 27/03/2015

Sobre as autoras:

Josieli Piovesan é mestre pelo Programa de Pós-Graduação em Envelhecimento Humano da Universidade de Passo Fundo (UPF-RS) e docente do curso de Psicologia da Universidade Regional Integrada do Alto Uruguai e das Missões - Campus de Frederico Westphalen (URI-RS).

E-mail: josipiovesan@hotmail.com

Silvana Alba Scortegagna é doutora em Psicologia pela Universidade São Francisco (USF-SP) e docente do Programa de Pós-Graduação em Envelhecimento Humano da Universidade de Passo Fundo (UPF-RS).

E-mail: silvanalba@upf.br

Ana Carolina Bertoletti De Marchi é doutora em Informática na Educação pela Universidade Federal do Rio Grande do Sul (UFRGS) e docente dos Programas de Pós-Graduação em Envelhecimento Humano e Computação Aplicada da Universidade de Passo Fundo (UPF-RS).

E-mail: carolina@upf.br

Contato com as autoras:

Josieli Piovesan

E-mail: josipiovesan@hotmail.com

Programa de Pós-Graduação Stricto Sensu em Envelhecimento Humano

Universidade de Passo Fundo

BR 285, Km 171, Bairro São José

Cx. Postal 611 - Passo Fundo/RS - Brasil

CEP: 99052-900

Psico-USF, Bragança Paulista, v. 20, n. 3, p. 505-515, set./ dez. 2015 
